Personality, education, diligence, knowledge, and clinical ability are conceded to the local consultants. Against this the appointing committee has no personal knowledge, as the old idea of interview has been abandoned, and the committee is probably a hundred miles away, out of reach of local opinion. As individual doctors these selectors would hesitate to risk a patient's life by prescribing by post; there seems no more justification for their actions here, with a professional life at stake.-I am, etc.,

Bournemouth.

\section{P. P. MCKINNEY.}

\section{The Maternity Service}

SIR,-I have received my copy of the statement issued by the Standing Maternity and Midwifery Advisory Committee of the Central Health Services Council (Supplement, Aug. 6, p. 74). It only confirms the gross defect in the maternity medical service scheme, which was obvious before it began to operate.

The conscientious family doctor who joined the Service has continued to do his maternity work exactly as before. On the other hand, it seems (vide Supplement, April 23, p. 248), some doctors have booked far more cases than before with the deliberate intention of doing the minimum of work for the maximum number of flat-rate fees. They have made a racket of the thing. This is not surprising; the regulations invite it.

Now comes this circular, with open encouragement for the racketeers, and a threat for the good G.P. obstetrician. Hands off ! We are not to pretend that we are in charge of our patients. We are the least essential members of a team.

I shall continue to tell my patients that the maternity scheme entitles them to engage me for their confinements if they wish. Being engaged, I shall " accept full responsibility for the antenatal care, the labour, and the lying-in period." If I am thrown out of the maternity service for this I shall be delighted.I am, etc.,

Cambridge.

H. R. Youngman.

** The Secretary of the Association writes: The General Medical Services Committee has dissociated itself from the contents of this circular and has asked the Ministry of Health to receive a deputation on the subject.

\section{POINTS FROM LETTERS}

\section{Income Reduced}

Dr. R. H. A. Ritchie (Sutton, Surrey) writes: After the first year of N.H.S. I am one of a large majority of G.P.s whose income has been substantially reduced as a result of the scheme. None of us can continue long under these conditions. What is the B.M.A. doing about this state of affairs ? It is galling to find that dentists are in clover. And who are of the greater value to the community, G.P.s or dentists?

\section{Allowance for Telephone Calls}

Dr. Thomas Leven (Irvine, Ayrshire) writes: Since the introduction of the National Health Service most hospitals have found it necessary to introduce an appointments system, which places upon the general practitioner the necessity of telephoning hospitals to make such appointments for patients who require examination by consultants or specialists. In the case of country and other practitioners who are some distance from suitable hospitals this duty involves considerable expense, which in my view is not adequately covered by the capitation fee. I request that the British Medical Association urge-nay, demand-that the Minister of Health and the Department of Health for Scotland accept the financial responsibilities of such calls, either by allowing their hospitals to accept reversed charges for legitimate calls or by an allowance for telephone calls to all practitioners on the same principle as the Mileage Fund.

\section{Universal Health Service}

Dr. JoHn DEBary (London, E.5) writes: A patient called to see me to-day with the following story. She was staying in Nice, and had a fall on the beach, as a result of which she hurt her varicose leg. She called a French doctor, who applied a dressing and a crêpe bandage. His bill was $23 \mathrm{~s}$. She asked me if there was any means of obtaining a refund of this fee from the N.H.S. Whatever next ?

Correction.-The Medical Practices Committee states that in the amended Schedule 2 of its Survey of General Practice (Supplement, Aug. 20, p. 93) Mildenwall should be spelt as here, and not Mildenhall.

\section{H.M. Forces Appointments}

\section{ROYAL NAVY}

Royal Naval Volunteer Reserve

Surgeon Lieutenant G. R. Kershaw to be Surgeon LieutenantCommander.

Temporary Acting Surgeon Lieutenant-Commander A. J. Ward has been transferred to List I of the Permanent R.N.V.R., in the rank of Surgeon Lieutenant.

\section{ARMY}

Colonel W. D. Anderton, M.C., late R.A.M.C., has retired on retired pay, and has been granted the honorary rank of Brigadier.

\section{ROYAL ARMY MEDICAL CORPS}

Lieutenant-Colonel J. M. MacKenzie, C.B.E., M.C., has retired on retired pay, and has been granted the honorary rank of. Brigadier. Lieutenant-Colonel J. F. Shepherd, M.B.E., I.M.S., retired, Retired and Re-employed, has ceased to be re-employed in the rank of Colonel as a Consultant, reverted to retired pay, and has been granted the honorary rank of Colcnel

Lieutenant-Colonel R. D. Davy, O.B.E., M.C., has retired on retired pay and has been granted the honorary rank of Colonel.

Majors W. F. Hooton, R. M. Henderson, and J. C. Scott, from Short Service (Specialist) Commissions, to be Maiors.

Major J. Walsh has retired on retired pay on account of disability. (Substituted for the notification in a Supplement to the London Gazette dated June 14.)

Short Service Commission, Specialist.-Major R. T. Fletcher, M.B.E., has retired, receiving a gratuity.

Temporary Commission.-Major H. Jacques, M.C., has relinquished his commission, retaining the rank of Major.

\section{REGULAR ARMY RESERVE OF OFFICERS}

Colonel H. C. D. Rankin, C.I.E., O.B.E., late R.A.M.C., having exceeded the age limit for liability to recall, has ceased to belong to the R.A.R.O., and has been granted the honorary rank of MajorGeneral.

Colonel E. P. Allman-Smith, O.B.E., M.C., late R.A.M.C., having exceeded the age limit for liability to recall, has ceased to belong to the R.A.R.O.

\section{Royal Army Medical Corps}

Major R. W. Chapman, having exceeded the age limit for liability to recall, has ceased to belong to the R.A.R.O., and has been granted the honorary rank of Lieutenant-Colonel.

Major S. P. Wilson, T.D., having exceeded the age limit for liability to recall, has ceased to belong to the Reserve of Officers.

Caplain (Honorary Major) C. G. Harper, having exceeded the age limit for liability to recall, has ceased to belong to the Reserve of Officers.

Captain and Brevet Major J. S. Sloper, O.B.E., having exceeded the age limit for liability to recall, has ceased to belong to the R.A.R.O., and has been granted the honorary rank of Colonel.

Captains and Brevet Majors R. C. Aitchison, F. H. Woods, G. H. Wood, E. J. Mannix, M. McGee Russell, H. J. Davidson, M.C., and C. W. Sparks, M.C., having exceeded the age limit for liability to recall, have ceased to belong to the R.A.R.O., and have been granted the honorary rank of Major.

Captains and Brevet Majors J. W. Cannon, A. G. P. Hardwick, M.C., H. Mitchell, and G. Fleming, having exceeded the age limit for liability to recall, have ceased to belong to the R.A.R.O.

Captain H. L. G. Hughes, C.B.E., D.S.O., M.C., having exceeded the age limit for liability to recall, has ceased to belong to the R.A.R.O., and has been granted the honorary rank of Brigadier.

Captain T. E. Osmond, having exceeded the age limit for liability to recall, has ceased to belong to the R.A.R.O., and has been granted the honorary rank of Colonel.

Captains C. J. O'Reilly, D.S.O., W. D. Whamond, A. G. Henderson, and G. Marshall having exceeded the áge limit for liability to recall, have ceased to belong to the R.A.R.O., and have been granted the honorary rank of Lieutenant-Colonel.

Captains G. D. Robertson, R. J. S. McDowall, H. A. Crouch, O.B.E., M.C., I. Aubrey, M.B.E., M.C., D. A. D. Kennedy, M.C., and $\mathbf{P}$. Reid, having exceeded the age limit for liability to recall, have ceased to belong to the R.A.R.O., and have been granted the honorary rank of Major.

\section{TERRITORIAL ARMY}

Royal Army Medical Corps

Major (Temporary Lieutenant-Colonel) A. G. Henderson, Reserve of Officers, has relinquished his T.A. Commission.

Captain R. F. Guymer, from T.A.R.O., to be Major, and has been granted the acting rank of Colonel.

Major S. P. Wilson, T.D., has relinquished his commission.

Captain C. J. Wells, M.B.E., to be Major.

Territorial Army Reserve of Officers: Royal Army Medical CORPS

Major (Acting Lieutenant-Colonel) J. B. Forsyth, T.D., from Active List, to be Major, relinquishing the acting rank of LieutenantColonel, and has been granted the honorary rank of Colonel. 